\title{
Hydrobiologia
}

\section{Nutrient uptake in a stream affected by hydropower plants: comparison between stream channels and diversion canals

\author{
--Manuscript Draft--
}

Manuscript Number:

Full Title:

Article Type:

Keywords:

Corresponding Author:

HYDR-D-12-07780R1

Nutrient uptake in a stream affected by hydropower plants: comparison between stream channels and diversion canals

SI: River Form and Function (Elosegi)

hydropower plant; stream; nitrogen; phosphorus; uptake; hydromorphology; water diversion

Arturo Elosegi, Ph.D.

University of the Basque Country

Bilbao, Biscay SPAIN

Corresponding Author Secondary

Information:

Corresponding Author's Institution:

University of the Basque Country

Corresponding Author's Secondary

Institution:

First Author:

Oihana Izagirre, Dr.

First Author Secondary Information:

Order of Authors:

Oihana Izagirre, Dr.

Alba Argerich, Dr.

Eugènia Martí, Dr.

Arturo Elosegi, Ph.D.

\section{Order of Authors Secondary Information:}

Abstract:

Response to Reviewers:
Small hydropower plants divert part of the water from wide and physically complex stream channels with active hyporheic areas to narrow and hydraulically simple concrete canals, and thus, might affect nutrient dynamics. We compared nutrient uptake in diversion canals and in stream channels in the Leitzaran Stream (Basque Country, northern Spain). We hypothesized that simple morphology in diversion canals will result in lower nutrient uptake in canals than in stream channels.

Periphytic chlorophyll and biomass did not differ significantly between reach types. Water was significantly deeper and faster in canals than in stream channels, but the transient storage zone did not differ significantly between reach types. There were no significant differences between uptake length for neither phosphate nor ammonium between reach types. Uptake length in both stream channels and diversion canals decreased with discharge, in a pattern similar to that previously described for pristine rivers across the world. Uptake velocity and uptake rate for phosphate did not differ significantly between reach types, but in the case of ammonium both retention metrics were significantly larger in the diversion canals. Results suggest that although hydropower schemes have minor effects on nutrient retention, these depend on the proportion of flow diverted.

Dear Michael,

We have followed carefully the comments made by you, Hervé and referee \#1 to our ms.

The only point in which we did no make so is in Line 295. The referee noticed a disagreement between text and table. The table was wrong, so instead of correcting the text we corrected the table. 
We hope the ms is now ready for publication.

Thank you very much for your effort

Arturo and Eugénia

Powered by Editorial Manager ${ }^{\circledR}$ and Preprint Manager ${ }^{\circledR}$ from Aries Systems Corporation 


\section{Nutrient uptake in a stream affected by hydropower plants:}

\section{2 comparison between stream channels and diversion canals}

3

4 Oihana Izagirre ${ }^{1}$, Alba Argerich ${ }^{2}$, Eugènia Marti ${ }^{3}$ and Arturo Elosegi ${ }^{1}$

5

$6 \quad{ }^{1}$ Department of Plant Biology and Ecology, Faculty of Science and Technology, the University of 7 the Basque Country, PO Box 644, 48080 Bilbao, Spain.

$8 \quad{ }^{2}$ Forest Ecosystems and Society Department, Oregon State University, Corvallis, Oregon, USA

$9 \quad$ 3Biogeodynamics \& Biodiversity Group, Centre d'Estudis Avançats de Blanes (CSIC), Accés a la

10 Cala St. Francesc 14, 17300 Blanes, Spain.

11 


\section{Abstract}

13 Small hydropower plants divert part of the water from wide and physically complex

14 stream channels with active hyporheic areas to narrow and hydraulically simple concrete canals, 15 and thus, might affect nutrient dynamics. We compared nutrient uptake in diversion canals and

16 in stream channels in the Leitzaran Stream (Basque Country, northern Spain). We hypothesized

17 that simple morphology in diversion canals will result in lower nutrient uptake in canals than in

18 stream channels.

19 Periphytic chlorophyll and biomass did not differ significantly between reach types. Water 20 was significantly deeper and faster in canals than in stream channels, but the transient storage 21 zone did not differ significantly between reach types. There were no significant differences 22 between uptake length for neither phosphate nor ammonium between reach types. Uptake 23 length in both stream channels and diversion canals decreased with discharge, in a pattern 24 similar to that previously described for pristine rivers across the world. Uptake velocity and 25 uptake rate for phosphate did not differ significantly between reach types, but in the case of 26 ammonium both retention metrics were significantly larger in the diversion canals. Results

27 suggest that although hydropower schemes have minor effects on nutrient retention, these

28 depend on the proportion of flow diverted.

30 Key Words: hydropower plant, stream, nitrogen, phosphorus, uptake, hydromorphology, water 31 diversion 


\section{Introduction}

Hydropower plants cause profound effects on river ecosystems by damming, reducing flow in natural stream channels, and creating new water flow paths through man-made side canals. Dams constitute barriers along the river continuum, which alter the downstream flux of water, sediments, nutrients and organic matter, and the movement of organisms (Ward \& Stanford, 1979). This in turn affects the channel morphology, community structure, and functioning of stream ecosystems (Graf, 1999; Petts, 1984; Ward et al., 1999; Elosegi et al., 2010). In addition, water diversion into artificial diversion canals reduces in-stream water flow, and thus modifies stream hydraulics and habitat characteristics affecting both invertebrates and fish communities (Armitage \& Petts, 1992; Hax \& Golladay, 1998; Murchie et al., 2008). There is less information on the effect of water diversion on stream ecosystem functioning, but impacts are likely, as both channel morphology and hydraulics exert a strong influence on ecosystem processes (Uehlinger, 2000; Hall et al. 2002; Sweeney et al. 2004; Elosegi et al. 2011). Finally, diversion canals can also be habitats for some organisms and play a role in the transport and processing of nutrients and organic matter, thus influencing ecosystem functioning of stream networks. However, there is little information on how diversion canals compare to stream channels regarding transport, retention and transformation of materials.

One of the ecosystem processes likely to vary between stream channels and man-made canals is nutrient uptake, because it is highly dependent on the interaction between hydrologic retention and both chemical and biological uptake (Valett et al., 1996) and these characteristics differ between both reach types. Diversion canals are morphologically more constrained and homogenous than natural river channels. Since they are often lined with concrete, they lack hyporheic zone, which is an active component of river ecosystems (Boulton et al., 1998). Furthermore, because diversion canals are managed to avoid flow obstructions, accumulation of sediments and organic matter is rare. Therefore, it is expected that the diversion canals have faster water velocity, less turbulence, and lower sediment-water interactions compared to the stream channels. All these physical characteristics suggest nutrient uptake would be lower in diversion canals than in stream channels (Mulholland et al. 1985; Gücker and Boëchat 2004; 
62 Roberts et al. 2007). Differences in nutrient uptake between canals and channels may in turn have implications for nutrient dynamics at the network scale in streams affected by hydropower

64 plants.

In the present study we compared nutrient uptake in two reach types: diversion canals and stream channels. We selected 5 canal-stream reach pairs downstream from water diversion dams, and an additional unregulated stream reach upstream from a dam. We hypothesized that channel form is an important factor controlling nutrient dynamics because it regulates interactions between water and bioreactive substrata. Therefore, we predict that simple morphology in diversion canals will result in lower nutrient uptake than in stream channels.

\section{Methods}

Study site

The Leitzaran is a $42 \mathrm{~km}$-long stream that drains a $114.5 \mathrm{~km}^{2}$ catchment (Fig. 1). Eighty five percent of the catchment area is dominated by siliceous geology, mostly carboniferous slate and sandstone. The stream is steep, sinuous, and runs along heavily incised meanders in a region with mountains higher than $1000 \mathrm{~m}$ a.s.l. located very close to the sea. The climate of the region is humid oceanic, with an average annual precipitation over $1500 \mathrm{~mm}$ and mean monthly temperatures ranging from $8.4^{\circ} \mathrm{C}$ in January to $20.7^{\circ} \mathrm{C}$ in August. Sixty six percent of the catchment is covered by conifer plantations (Pinus radiata up to 400-500 m a.s.l., Larix kaempferi at higher altitudes, and some sparse stands of Pseudotsuga menziesii), $18 \%$ is covered by native deciduous forests of oak (Quercus robur), beech (Fagus sy/vatica), birch (Betula spp.), chestnut (Corylus avellana) and alder (Alnus glutinosa). The rest of the catchment (16\%) consists of pasture land, meadows and few patches of arable land. 
sheep and cattle. The wastewater from Leitza receives secondary treatment before it is delivered into the stream. Areso has 290 inhabitants, mostly devoted to farming and forestry activities. Four km downstream from Leitza and Areso the Leitzaran Stream enters the province of Guipuscoa. At this location, the average concentrations of nitrate $\left(\mathrm{NO}_{3}{ }^{-} \mathrm{N}\right)$, ammonium $\left(\mathrm{NH}_{4}{ }^{+}-\mathrm{N}\right)$, and phosphate $\left(\mathrm{PO}_{4}{ }^{3-}-\mathrm{P}\right)$ are relatively high $\left(1.37,0.10\right.$ and $0.05 \mathrm{mg} \mathrm{L}^{-1}$, respectively); however, invertebrate-based biotic indices indicate excellent water quality (Government of Navarre, 2005). Downstream from this point, the Leitzaran Stream runs for 30 $\mathrm{km}$ along a scarcely populated valley that is protected under the legal figure of Protected Biotope before it joins the Oria river. Nutrient concentrations tend to decrease along this reach.

Along the Leitzaran Stream there are 6 hydropower plants and 8 diversion dams, which are mostly concentrated in the lower $30 \mathrm{~km}$ of the stream (Fig. 1). Along this part, stream hydrology is highly influenced by the operation of these plants. Seventy percent of the stream length is affected by water diversion into canals, which run in parallel to the stream channel until they release the water at downstream locations, and an additional $4.1 \%$ is affected by water impoundments generated by dams. In this study, we selected 5 sites located at diversion dams (Fig. 1). One site was located in a headwater tributary (Franki) and the rest of sites were arranged along the main stem of the Leitzaran Stream (Plazaola, Mustar, Ameraun and Bertxin). Characteristics of each hydropower plant are shown in Table 1. Water concessions to hydropower companies (Table 1) are set to maintain environmental stream flows below the dams except at Franki and Plazaola, which are older concessions.

114 was selected upstream from the dam and used as a reference for unregulated flow conditions.

115 The diversion canal from Ameraun returns its water to the stream at a site located below

116 Bertxin (i.e., the next sampling site). Therefore, stream discharge at Bertxin is affected by 117 water abstraction from both the Bertxin and Ameraun canals (Fig. 1). 
120 The study was done between the $15^{\text {th }}$ and $19^{\text {th }}$ of May 2006. On each day, we sampled

121 sequentially both the canal and stream reaches of a study site, so that the delay between both

122 additions was typically less than 2 hours. At each reach we measured stream nutrient (i.e.,

$123 \mathrm{NH}_{4}{ }^{+}-\mathrm{N}$ and $\mathrm{PO}_{4}{ }^{3-}-\mathrm{P}$ ) uptake using the pulse nutrient addition technique (Wilcock et al., 2002).

124 We used this method because high discharge, especially in the canals, precluded the application

125 of the more widely used constant-rate addition technique (Webster \& Valett, 2006).

126 Nevertheless, Powers et al. (2009) have recently shown that the two methods provide

127 comparable results of nutrient uptake metrics. On each addition, 20-50 L of a solution

128 containing $\mathrm{NH}_{4} \mathrm{Cl}$ and $\mathrm{Na}\left(\mathrm{H}_{2} \mathrm{PO}_{4}\right) \cdot \mathrm{H}_{2} \mathrm{O}$ as nutrient sources, and $\mathrm{NaCl}$ as a hydrologic tracer

129 (Bencala et al. 1987) were added to the stream or canal in a single pulse at the head of the

130 reach, in a place were fast mixing with stream water was ensured. In the case of the canals, we

131 took advantage of the strong turbulence in the transition between the weir and the canal. The

132 amount of reagents in the solution was set to target a 3-fold increase in background nutrient

133 concentration at the peak of the pulse. Conductivity was automatically recorded at the

134 downstream end of the reach every $5 \mathrm{~s}$ from the beginning of the addition pulse until

135 conductivity returned to pre-addition values using a conductivity meter (WTW 330) connected

136 to a data logger (Campbell CR 510). Water samples were collected in $250 \mathrm{~mL}$ acid-washed

137 plastic bottles every $10-60 \mathrm{~s}$ at the bottom of the reach over the conductivity-pulse passage.

138 Samples were stored on ice, transported to the laboratory, filtered through pre-ashed fiberglass

139 filters (Whatman GF/F), and frozen until analysis. Concentrations of $\mathrm{PO}_{4}{ }^{3-}-\mathrm{P}$ and $\mathrm{NH}_{4}{ }^{+}-\mathrm{N}$ were

140 analyzed manually and using TRAACS 800 autoanalyzer, respectively, following standard

141 colorimetric methods (APHA, 1998).

143 Additionally, reach morphology was described by means of 10 regularly spaced transects,

144 across which measurements were recorded at $0.5-1 \mathrm{~m}$ intervals. At each transect, we

145 measured wetted width $(w, \mathrm{~m})$, water depth $(h, \mathrm{~m})$, percentage coverage of substrate types

146 (silt, sand, gravel, pebble, cobble, boulder or bedrock), presence of wood and leaf litter, and

147 canopy cover (measured as the vertical projection of leaf shade). We also measured water 
148 temperature, $\mathrm{pH}$ and oxygen concentration (WTW field probes). To estimate the accumulated

149 radiation reaching the reach during the addition experiments, we corrected radiation data

150 provided by the Meteorological Survey of the Basque Government for the shade produced by

151 the canopy cover on each reach. The light attenuation was estimated using the ratios calculated

152 by Izagirre and Elosegi (2004) at a full-canopy site with summer foliage.

154 At each reach we also collected periphyton samples to estimate biomass and pigment content. In the stream reaches, ten cobbles were collected at random, an area of $18.6 \mathrm{~cm}^{2}$ was

156 scraped from each cobble using scalpels and toothbrushes, and periphyton samples were

157 collected with Pasteur pipettes. In the canal reaches, 10 samples were collected from the 158 bottom and side-walls of the canal with a modified syringe (Biggs \& Kilroy, 2000). All periphyton

159 samples were stored in $50 \mathrm{~mL}$ plastic containers, brought to the laboratory on ice and kept

160 frozen until analysis. After thawing, samples were homogenized with a domestic blender. One

161 sub-sample was used to determine biomass as ash-free dry mass (AFDM) after drying at $105^{\circ} \mathrm{C}$

162 for $24 \mathrm{~h}$ and ashing at $500{ }^{\circ} \mathrm{C}$ for $4 \mathrm{~h}$. Another sub-sample was used to measure chlorophyll $\mathrm{a}$

163 spectrophotometrically after extraction in hot ethanol (Sartory \& Grobbelaar, 1984).

\section{Calculation of hydraulic parameters}

166 Several hydraulic parameters were estimated from the time-conductivity curves obtained 167 during the nutrient addition pulse at the end of the reach. Average water velocity $\left(\mathrm{v}, \mathrm{m} \mathrm{s}^{-1}\right)$ was 168 calculated dividing reach length by the time elapsed between the addition and the conductivity 169 peak (i.e., mean travel time). Discharge $\left(\mathrm{Q}, \mathrm{L} \mathrm{s}^{-1}\right)$ was estimated based on a mass balance 170 approach using conductivity data as a surrogate of the chloride concentration. Briefly, discharge 171 was the result of multiplying the volume of the added solution (L) by its conductivity $\left(\mu \mathrm{S} \mathrm{cm}^{-1}\right)$

172 and dividing it by the integrated area of the conductivity curve above ambient conductivity

173 levels $\left(\mu \mathrm{S} \mathrm{s} \mathrm{cm}^{-1}\right)$. Parameters to characterize the water transient storage along each study 174 reach were estimated from the conductivity data by a one-dimensional solute transport model 175 with inflow and storage (OTIS, Runkel, 1998). Estimated parameters from the model were a)

176 the cross-sectional area of the wetted channel $\left.\left(A, \mathrm{~m}^{2}\right), \mathrm{b}\right)$ the storage zone cross-sectional area 
$177\left(A_{s}, m^{2}\right)$, and $\left.c\right)$ the water exchange rate from free flowing water to transient storage zone $\left(k_{1}\right.$,

$178 \mathrm{~s}^{-1}$ ). To allow comparison among reaches, $A_{s}$ was normalized by $A$ (i.e., $A_{s} / A$ ratio). This ratio

179 was used to estimate the water exchange rate from transient storage zone to free flowing

180 water $\left(\mathrm{k}_{2}, \mathrm{~s}^{-1}\right)$ using the equation:

181

$$
\frac{A_{s}}{A}=\frac{k_{1}}{k_{2}}
$$

182

\section{Calculation of nutrient uptake metrics} concentration data from the pulse additions: uptake length $\left(S_{w}, m\right)$, uptake velocity $\left(V_{f}, m m\right.$ $\left.\mathrm{min}^{-1}\right)$ and uptake rate at ambient levels $\left(\mathrm{U}, \mu \mathrm{g} \mathrm{m}^{-2} \mathrm{~s}^{-1}\right) . \mathrm{S}_{\mathrm{w}}$ is the average distance travelled by

187 a nutrient molecule before being removed from the water column (Newbold et al. 1981), and reflects nutrient uptake efficiency in terms of nutrient removal relative to nutrient flux. $V_{f}$ is the velocity at which a molecule moves from the water column to the stream bed, and it is an index of the biological nutrient demand (Stream Solute Workshop, 1990). $U$ is the mass of nutrient taken per unit of stream bottom area and unit of time, and indicates the stream nutrient uptake capacity (Stream Solute Workshop, 1990). predicted from the time-through curve of conductivity. We assumed predicted nutrient concentrations to be solely influenced by advection, dispersion and dilution, whereas observed nutrient concentrations were additionally subjected to biological or chemical uptake processes. Predicted concentrations were calculated using the following equation:

$$
N_{t(\text { pred })}=\frac{\text { Cond }_{t}-\text { Cond }_{b}}{\text { Cond }_{i}} \mathrm{i}_{i}+N_{b}
$$


where $\mathrm{N}_{t}$ and $\mathrm{N}_{\mathrm{b}}$ are nutrient concentrations $\left(\mathrm{mg} \mathrm{L}^{-1}\right)$ measured at time $t$ and at background, respectively. This equation assumes that changes in background-corrected nutrient concentrations over time relative to the nutrient concentration of the added solution $\left(\mathrm{N}_{\mathrm{i}}\right)$ are equal to changes in background-corrected conductivity $\left(\right.$ Cond $_{t}-$ Cond $\left._{b}\right)$ over time relative to conductivity of the added solution $\left(\right.$ Cond $\left._{\mathrm{i}}\right)$. The total mass of nutrient added to the reach $\left(\mathrm{M}_{\mathrm{i}}\right.$ $\mathrm{mg})$ and the total mass of nutrients retrieved at the end of the reach $\left(\mathrm{M}_{\mathrm{t}}, \mathrm{mg}\right)$ were calculated as the integrated area of the background-corrected nutrient concentration-time curve $\left(\mathrm{N}_{\mathrm{t}}, \mathrm{mg} \mathrm{L}^{-}\right.$ $\left.{ }^{1} \mathrm{~s}^{-1}\right)$ multiplied by discharge $\left(\mathrm{Q}, \mathrm{L} \mathrm{s}^{-1}\right)$ using predicted and measured nutrient concentrations,

\section{1 respectively.}

$$
M_{i, t}=Q \int_{0}^{\infty} N_{t} d t
$$

214 Based on these two values, we estimated the nutrient uptake rate coefficient $\left(k_{t}, s^{-1}\right)$ following 215 the exponential decay model (Martí and Sabater, 2009):

$$
M_{t}=M_{i} e^{-k_{t} t_{n}}
$$

217 where $t_{n}$ is the mean water travel time (s) along the reach. The nutrient uptake metrics were 218 derived from $k_{t}$ using the following equations: width to account for the surface of the side walls.

\section{Data analysis}

We examined the normality of the variables by means of the Shapiro-Wilk test, and the homogeneity of variances by the Levene's statistic. In order to meet assumptions of normality, 
prior to the statistical analysis of data all variables were log-transformed. Differences in chlorophyll and benthic AFDM were analyzed by means of two-way ANOVA tests (stream site

231 and reach type as factors). Student's t-tests for paired samples were used to compare data

232 from all measured variables between stream and canal reaches. periphytic biomass, and nutrient concentrations using univariate lineal regression. Differences in regression models between stream and canals were analyzed using ANCOVA. In particular, we examined the relationships between a) $S_{w}$ and $Q, h$ and $\left.v, b\right) V_{f}$ and water transient storage parameters and nutrient concentrations, and c) $\mathrm{U}$ and periphytic biomass. The significance level for the tests was $p=0.05$. All statistical analyses were done using SPSS for Windows (version 12.0, SPSS Inc., Chicago).

\section{Results}

Chemical and biological characterization

Light levels during the addition were significantly higher at stream channels than at diversion canals (Student's paired t-test, $\mathrm{t}=3.415, \mathrm{p}=0.027$ ). Water temperature ranged from 11.1 to $18.2^{\circ} \mathrm{C}$ among sites, conductivity from 65.7 to $259.1 \mu \mathrm{S} \mathrm{cm}{ }^{-1}$ and $\mathrm{pH}$ from 7.07 to 8.10 (Table 2). Dissolved oxygen concentration during the pulse additions ranged from 9.7 to 10.6 $\mathrm{mg} \mathrm{O}_{2} \mathrm{~L}^{-1}$, which corresponds to $100-106 \%$ saturation. Concentration of nutrients was low to moderate, ranging from 0.004 to $0.060 \mathrm{mg} \mathrm{L}^{-1}$ for $\mathrm{PO}_{4}{ }^{3-}-\mathrm{P}$, and from 0.008 to $0.044 \mathrm{mg} \mathrm{L}^{-1}$ for $\mathrm{NH}_{4}{ }^{+}-\mathrm{N}$ (Table 2). Neither nutrient followed any clear longitudinal pattern along the Leitzaran Stream. None of the variables described above showed any significant difference between the two reach types (Student's paired t-test, $\mathrm{p}>0.05$ ). Periphytic Chl $a$ ranged from 2.4 to 120.5 $\mathrm{mg} \mathrm{m}^{-2}$, and biomass from 3.9 to $21.8 \mathrm{~g} \mathrm{AFDM} \mathrm{m}^{-2}$. These two variables showed no clear patterns along the stream, and did not significantly differ between the two reach types nor among sites. 
The canals were more homogeneous than the stream reaches in terms of substrata.

260 Canals were dominated by concrete, although the canal at Plazaola had a considerable

261 accumulation of leaf litter. On the other hand, stream channels were dominated by cobble-

262 boulder substrata (Table 3).

263

Total discharge (stream + canal) increased from $77.5 \mathrm{~L} \mathrm{~s}^{-1}$ at Franki to $870 \mathrm{~L} \mathrm{~s}^{-1}$ at

Ameraun (Table 3). The decrease in Q observed at the most downstream site (Bertxin) is explained because the canal from Ameraun reverts its water downstream of Bertxin. At each site, the dams diverted more than $75 \%$ of the total stream discharge into the diversion canals, except at Bertxin (14\%), because the hydropower plant was operating well below its full capacity. Streams were wider than canal reaches at all sites except Franki, where $99 \%$ of total discharge was diverted, leaving only a rivulet in the stream channel (Table 3). Mean water depth was below $20 \mathrm{~cm}$ at stream reaches and from $20 \mathrm{~cm}$ to $1 \mathrm{~m}$ at the canals, differences between reach types being statistically significant (paired Student's t-test, $t=-3.534, p=$ $0.024)$. Water velocity ranged from 0.02 to $0.31 \mathrm{~m} \mathrm{~s}^{-1}$ in stream reaches and from 0.29 to 0.52 $\mathrm{m} \mathrm{s}^{-1}$ in canal reaches, being significantly slower in the stream than in the canal reaches (paired Student's t-test, $\mathrm{t}=-5.538, \mathrm{p}=0.005)$.

Values of A were higher in the canals than in the stream reaches at all sites except Bertxin (Table 3). A was related to $\mathrm{Q}$, but the relationship did not differ significantly between stream and canal reaches (ANCOVA). Taking all data together the relationship followed a potential model $\left(A=0.0365 Q^{0.565}, r^{2}=0.856, p<0.001\right)$. Reach types did not significantly differ in $A_{s}$ (paired Student's t-test, $t=1.749, p=0.155$ ) nor in the $A_{s} / A$ ratio (paired Student's

$282 \mathrm{t}$-test, $\mathrm{t}=2.342, \mathrm{p}=0.079$ ). This ratio was negatively related to $\mathrm{Q}$ but the relationship did not 283 differ significantly between stream and canal reaches (ANCOVA). Taking all data together the relationship followed a logarithmic model $\left(A_{s} / A=0.684-0.097 \operatorname{Ln} Q, r^{2}=0.816, p<0.001\right) . k_{1}$

285 showed no significant differences between reach types, but $k_{2}$ was significantly higher in the 286 canals than in the stream channels (paired Student's t-test, $t=-7.222, p=0.002$ ). 
Nutrient uptake

Values of $\mathrm{S}_{\mathrm{w}}$ for $\mathrm{PO}_{4}{ }^{3-}-\mathrm{P}$ ranged from 14 to $195 \mathrm{~m}$ at stream reaches, including the upstream site at Franki, and from 97 to $577 \mathrm{~m}$ at canal reaches (Fig. 2). Contrary to our prediction, it was not significantly different between reach types (Table 4). $\mathrm{S}_{\mathrm{w}}$ for $\mathrm{PO}_{4}{ }^{3-}$ was positively related to water depth $\left(S_{w} P=63.9+428 h, r^{2}=0.524, p=0.012\right)$. Values of $V_{f}$ for $\mathrm{PO}_{4}{ }^{3-}-\mathrm{P}$ ranged from 6 to $20 \mathrm{~mm} \mathrm{~min}^{-1}$ at stream reaches, and from 6 to $97 \mathrm{~mm} \mathrm{~min}{ }^{-1}$ at canal reaches (Fig. 2), and were not significantly different between reach types (Table 4). Values of $U$ for $\mathrm{PO}_{4}^{3-}-\mathrm{P}$ ranged from 1.2 to $12.5 \mu \mathrm{g} \mathrm{m}^{-2} \mathrm{~s}^{-1}$ at stream reaches and from 1.0 to $26.7 \mu \mathrm{g} \mathrm{m}^{-2} \mathrm{~s}^{-1}$ at canal reaches (Fig. 2); as with the other uptake metrics, differences were not statistically significant (Table 4). $\mathrm{V}_{\mathrm{f}}$ and $\mathrm{U}$ for $\mathrm{PO}_{4}{ }^{3-}$ were not significantly related to any of the independent variables considered. independent variables considered. (Fig. 2), and, as in the case for phosphate, showed no significant differences between reach types (Table 4). $\mathrm{S}_{\mathrm{w}}$ for $\mathrm{NH}_{4}{ }^{+}$was positively related to discharge $\left(\mathrm{S}_{\mathrm{w}} \mathrm{N}=89.6+0.463 \mathrm{Q}, \mathrm{r}^{2}=\right.$ $0,654, p=0.005)$ and water depth $\left(\mathrm{S}_{\mathrm{w}} \mathrm{N}=68.1+372 \mathrm{~h}, \mathrm{r}^{2}=0.69, \mathrm{p}=0.003\right) . \mathrm{V}_{\mathrm{f}}$ for $\mathrm{NH}_{4}{ }^{+}-\mathrm{N}$ ranged from 2 to $15 \mathrm{~mm} \mathrm{~min}^{-1}$ in stream reaches and from 12 to $58 \mathrm{~mm} \mathrm{~min}^{-1}$ in canals, being significantly higher in canal than in stream reaches (Table 4). Values of $\mathrm{U}$ for $\mathrm{NH}_{4}{ }^{+}-\mathrm{N}$ ranged from 0.7 to $8 \mu \mathrm{g} \mathrm{m}^{-2} \mathrm{~s}^{-1}$ in streams, and from 8 to $26 \mu \mathrm{g} \mathrm{m}^{-2} \mathrm{~s}^{-1}$ in canals, differences being statistically significant (Table 4). $\mathrm{V}_{\mathrm{f}}$ and $\mathrm{U}$ for $\mathrm{NH}_{4}{ }^{+}$were not significantly related to any of the the $\mathrm{S}_{\mathrm{w}}-\mathrm{N}: \mathrm{S}_{\mathrm{w}}-\mathrm{P}$ ratio $1.5-4.5$ ) whereas no consistent pattern was found in the canals (range of

312 the $\mathrm{S}_{\mathrm{w}}-\mathrm{N}: \mathrm{S}_{\mathrm{w}}-\mathrm{P}$ ratio $\left.0.5-1.7\right)$. 


\section{Discussion}

317 Morphologically, diversion canals contrast sharply with stream channels, as they are

318 narrower, deeper and have lower substrata heterogeneity. Contrasting with this apparent

319 difference, our study showed only small hydraulic differences between diversion canals and

320 stream channels. Water velocity in canals was much faster than in stream channels, but

321 differences in other hydraulic variables were less consistent between reach types. This may be

322 explained in part by differences in total discharge and in the fraction of water diverted among

323 study sites. The active channel was in all cases wider in stream channels than in diversion

324 canals. Nevertheless, changes in discharge in canals only affect water depth, whereas in stream

325 channels affect both depth and wetted width, due to differences in shape of cross-sections

326 (Jain, 2001). Therefore, when most water was diverted, like observed at Franki, the cross

327 section was smaller in the stream than in the canal, whereas in cases where only a small

328 fraction of the flow was diverted, like in Bertxin, the reverse was true.

330 Canals were characterized by smoother substrata than stream channels, and by reduced

331 or absent hyporheos and dead zone storage. These features could result in smaller size of

332 transient storage and lower water retention within the canal reaches, as both parameters are

333 influenced by geomorphic complexity of the channel (Gooseff et al., 2007; Zarnetske et al.,

334 2007). Nevertheless, and contrary to our predictions, the size of water transient storage and its

335 exchange with free-flowing water in the Leitzaran did not consistently differ between reach

336 types. The lack of consistent differences in hydraulic parameters between canal and stream

337 reaches probably was not caused by uncertainty of the estimates, as estimated dispersion

338 coefficients were below $0.20 \mathrm{~m} \mathrm{~s}^{-2}$. We observed a negative relationship between the size of the

339 transient storage $\left(A_{s} / A\right)$ and discharge when pooling data from all sites together, in agreement

340 with previous studies (Argerich et al., 2008). This relationship indicates that hydrology may

341 override the effect of channel morphology on the variation of transient storage. In fact, at all

342 the sites where a large fraction of the water was diverted (4 out of 5 sites) the transient

343 storage size was larger at stream channels than at diversion canals. At Bertxin, where the canal 
344 diverted only $14 \%$ of the stream flow, the contrary was observed, but even there the transient

345 storage size was not very large at the canal, probably limited by its low physical complexity.

346 Other factors that may explain a lack of consistent differences could be associated with

347 accumulation of benthic organic matter in the canals. Benthic organic matter is known to

348 increase $A_{s} / A$ in streams (Hart et al. 1999; Haggard and Storm 2003; Jin and Ward 2005;

349 Argerich et al., 2008), and may also play a role in some of the diversion canals.

Contrary to our prediction, stream channels and canals did not differ in nutrient uptake

352 efficiency. The nutrient uptake lengths measured along the Leitzaran Stream were in the order

353 of few hundreds of metres, indicating relatively high nutrient uptake efficiency regardless of

354 reach type. These values were similar to those published for headwater streams (e.g., Webster

355 et al., 2003). In fact, the values measured in the Leitzaran fit within the relationship between

356 uptake length and discharge described by Martí et al. (2004) from results compiled from the

357 literature (Fig. 3). This provides further support to previous studies stating that discharge is the

358 main factor controlling nutrient uptake efficiency in rivers (Butturini \& Sabater 1998; Peterson

359 et al. 2001). Considering data from the Leitzaran only, this relationship was significant for

360 ammonium uptake length, but not for phosphate. However, phosphate uptake length was

361 significantly related to depth, a variable directly linked to discharge. Therefore, it seems that

362 hydrology overrides the effects of other variables, like physical channel complexity or the

363 presence of hyporheos, thus, offering some clues to predict the nutrient uptake response of

364 streams to variations in water diversion.

366 When uptake length values were corrected by discharge (i.e., estimated $V_{f}$ ), differences

367 were significant between reach types for ammonium but not for phosphate. $\mathrm{V}_{\mathrm{f}}-\mathrm{N}$ values in the

368 stream channels were similar to those reported in the literature for mountain streams (e.g., Hall

369 et al. 2002; von Schiller et al. 2008), but were up to an order of magnitude higher in the canals.

370 These differences were also observed for ammonium uptake rates. Other authors (e.g., Kent et

371 al. 2005; Knap et al. 2009) have also shown fast nutrient retention in concrete-lined channels. 
372 Abiotic sorption provides a potential explanation for the increased uptake in the canals (e.g.,

373 Boatman and Murray 1982; Triska et al. 1994), but biological activity could play a more crucial

374 role. Primary producers show great affinity for dissolved nutrients (Webster et al. 2003) and

375 affect uptake rates (Sabater et al. 2000; Mulholland et al. 2006). Canals have more stable

376 substrate, more uniform current, and lower siltation (especially in the lateral walls) what would

377 favour growth of primary producers such as filamentous green algae and mosses (Wood \&

378 Armitage 1997; Cardinale 2011). In fact, we observed that mosses covered most of the bottom

379 and side walls of the studied canals. Some studies have highlighted that aquatic bryophytes

380 have high capacity to retain nutrients (Mulholland et al. 2000), at least during some seasons

381 (Steinman \& Boston 1993).

382

383 In summary, our results show that the morphological contrast between stream channels

384 and diversion canals do not result in consistent differences in transient storage and nutrient

385 uptake efficiency. Instead, these variables seem to depend primarily on discharge, regardless of

386 reach type. In addition, we found that canals had higher ammonium demand than expected.

387 Therefore, the overall effect of hydropower plants on nutrient export from the stream-canal

388 network can depend on operational decisions upon the proportion of water diverted into the

389 canals.

390

\section{Acknowledgements}

392 This research has been funded by the Spanish Department of Science and Technology, 393 the University of the Basque Country, and the European Regional Development Fund, through

394 projects 9/UPV00118.310-14476/2002 and BOS2003-04466. The authors want to thank Félix

395 Izco and Patxi Tamés (Province Government of Guipuscoa), for continuous support. Oihana

396 Izagirre did this work thanks to a pre-doctoral grant by the Basque Government.

\section{References}

399 APHA, 1998. Standard methods for the examination of water and wastewater. 20th edition.

$400 \quad$ American Public Health Association, Washington, D.C. 
Argerich, A., E. Martí, F. Sabater, M. Ribot, D. von Schiller \& J. L. Riera, 2008. Combined effects of leaf litter inputs and a flood on nutrient retention in a Mediterranean mountain stream during fall. Limnology and Oceanography 53: 631-641.

Armitage, P.D. \& G. E. Petts, 1992. Biotic score and prediction to assess the effects of water abstractions on rivermacroinvertebrates for conservation purposes. Aquatic Conservation: Marine and Freshwater Ecosystems 2: 1-17.

Bencala, K.E., D. M. McKnight \& G. W. Zellweger, 1987. Evaluation of natural tracers in an acidic and metal-rich stream. Water Resources Research 23: 827-836.

Biggs, B. J. F. \& C. Kilroy, 2000. Stream periphyton monitoring manual. New Zealand Ministry for the Environment/ NIWA, Christchurch, New Zealand.

Boatman, C. D. \& J. W. Murray, 1982. Modeling exchangeable $\mathrm{NH}^{4+}$ adsorption in marinesediments - process and controls of adsorption. Limnology and Oceanography 27: 99110.

Boulton, A. J., S. Findlay, P. Marmonier, E. H. Stanley \& H. M. Vallet, 1998. The functional significance of the hyporheic zone in streams and rivers. Annual Review of Ecology and Systematics 29: 59-81.

Butturini, A. \& F. Sabater, 1998. Ammonium and phosphate retention in a Mediterranean stream: hydrological versus temperature control. Canadian Journal of Fisheries and Aquatic Sciences 55: 1938-1945.

Cardinale, B.J., 2011. Biodiversity improves water quality through niche partitioning. Nature 472: 86-89.

Elosegi, A., J. R. Díez \& M. Mutz, 2010. Effects of hydromorphological integrity on biodiversity and functioning of river ecosystems. Hydrobiologia 657: 199-215.

Elosegi, A., L. Flores \& J. R. Díez, 2011. The importance of local processes on habitat characteristics: a Basque stream case study. Limnetica 30: 183-196. 
426 Gooseff, M. N., R. O. Hall \& J. L. Tank, 2007. Relating transient storage to channel complexity in streams of varying land use in Jackson Hole, Wyoming. Water Resources Research 43. DOI: $10.1029 / 2005$ WR004626

Government of Navarre, 2005. Estudio de determinación de índices bióticos en 87 puntos de los ríos de Navarra. Government of Navarre, Pamplona, Spain.

431 Graf, W. L., 1999. Dam nation: A geographic census of American dams and their large-scale hydrologic impacts. Water Resources Research 35: 1305-1311.

Gücker, B \& I. G. Boëchat, 2004. Stream morphology controls ammonium retention in tropical headwaters. Ecology 85: 2818-2827.

Haggard, B. E. \& D. E. Storm, 2003. Effect of leaf litter on phosphorus retention and hydrological properties at a first order stream in northeast Oklahoma, USA. Journal of

Hall, R. O., E. S. Bernhardt \& G. E. Likens, 2002. Relating nutrient uptake with transient storage in forested mountain streams. Limnology and Oceanography 47: 255-265.

Hart, D. R., P. J. Mulholland, E. R. Marzolf, D. L. DeAngelis \& S. P. Hendricks, 1999. Relationships between hydraulic parameters in a small stream under varying flow and seasonal condition. Hydrological Processes 13: 1497-1510

Hax, C. L. \& S. W. Golladay, 1998. The effects of a man-made flow disturbance on macroinvertebrate communities of a north Texas prairie stream. American Midland periphytic biomass in a north Iberian stream. Annales de Limnologie 41: 35-46.

Jain, S. C., 2001. Open-channel flow. Wiley. 
Jin, H. S. \& G. M. Ward, 2005. Hydraulic characteristics of a small Coastal Plain stream of the southeastern United States: effects of hydrology and season. Hydrological Processes 19: $4147-4160$.

452

Kent, R., K. Belitz \& C.A. Burton, 2005. Algal productivity and nitrate assimilation in an effluent dominated concrete lined stream. Journal American Water Resources Association 41: $1109-1128$.

Knapp, C.W., W.K. Dodds, K.C. Wilson, J.M. O'Brien \& D.W. Graham, 2009. Biogeography of denitrification genes in a highly homogenous urban stream. Environmental Science and Technology 43: 4273-4279.

Martí, E. \& F. Sabater, 2009. Retención de nutrientes en ecosistemas fluviales. In Conceptos y técnicas en ecología fluvial, Elosegi A and Sabater S (eds), Fundación BBVA, Bilbao, España.

Martí, E., J. Aumatell, L. Godé, M. Poch \& F. Sabater, 2004. Nutrient retention efficiency in streams receiving inputs from wastewater treatment plants. Journal of Environmental Quality 33: 285-293.

Murchie, K. J., K. P. E. Hair, C. E. Pullen, T. D. Redpath, H. R. Stephens \& S. J. Cooke, 2008. Fish response to modified flow regimes in regulated rivers: research methods, effects and opportunities. River Research and Applications 24: 197-217

Mulholland, P. J., J. D. Newbold, J. W. Elwood \& J. R. Webster, 1985. Phosphorus spiralling in a woodland stream: Seasonal variations. Ecology 66: 1012-1023.

Mulholland, P. J., J. L. Tank, D M. Sanzone, W. M. Wollheim, B. J. Peterson, J. R. Webster \& J. L. Meyer, 2000. Nitrogen cycling in a forest stream determined by a ${ }^{15} \mathrm{~N}$ tracer addition. Ecological Monographs 70: 471-493. 
Mulholland, P. J., S. A. Thomas, H. M. Valett, J. R. Webster \& J. Beaulieu, 2006. Effects of light on nitrate uptake in small forested streams: diurnal and day-to-day variations. Journal of the North American Benthological Society 25: 583-595.

475

476

477

478

479

480

Newbold, J. D., J. W. Elwood, R. V. O'Neil \& W. Van Winkle, 1981. Measuring nutrient spiraling in streams. Canadian Journal of Fisheries and Aquatic Sciences 38: 860-863.

Peterson, B. J., W. Wolheim, P. J. Mulholland, J. R. Webster, J. L. Meyer, J. L. Tank, N. B. Grimm, E. Martí, W. B. Bowden, H.M. Vallet, A. E. Hershey, W.B. McDowell, W.K. Dodds, S. K. Hamilton, S.V. Gregory \& D. J. D’Angelo, 2001. Control of nitrogen export from watersheds by headwater streams. Science 292: 86-90.

Petts, G. E., 1984. Impounded rivers - perspectives for ecological management. John Wiley and Sons: Chichester, UK.

Powers, S. M., E. H. Stanley \& N. R. Lottig, 2009. Quantifying phosphorus uptake using pulse and steady-state approaches in streams. Limnology and Oceanography Methods 7: 498508.

Roberts, B. J., P. J. Mulholland \& A. N. Houser, 2007. Effects of upland disturbance and instream restoration on hydrodynamics and ammonium uptake in headwater streams. Journal of the North American Benthological Society 26: 38-53.

Runkel, R. L., 1998. One-dimensional transport with inflow and storage (OTIS): A solute transport model for streams and rivers. U.S. Geological Survey Water-Resources Investigation Report 98-4018, Denver, CO.

Sabater, F., A. Buturini, E. Martí, I. Muñoz, A. Romaní, J. Wray \& S. Sabater, 2000. Effects of riparian vegetation removal on nutrient retention in a Mediterranean stream. Journal of the North American Benthological Society 19: 609-620.

Sartory, D. P. \& J. E. Grobbelaar, 1984. Extraction of chlorophyll a from freshwater phytoplankton for spectrophotometric analysis. Hydrobiologia 114: 177-187. 
Steinman, A. D. \& H.L. Boston, 1993. The ecological role of aquatic bryophytes in a woodland stream. Journal of the North American Benthological Society 12: 17-26.

Stream Solute Workshop, 1990. Concepts and methods for assessing solute dynamics in stream ecosystems. Journal of the North American Benthological Society 9: 95-119.

Sweeney, B. W., T. L. Bott, J. K. Jackson, L. A. Kaplan, J. D. Newbold, L. J. Standley, W. C. Hession \& R. J. Horwitz, 2004. Riparian deforestation, stream narrowing, and loss of ecosystem services. Proceedings of the National Academy of Sciences 101: 1413214137.

Triska, F. J., A. P. Jackman, J. H. Duff \& R. J. Avanzino. 1994. Ammonium sorption to channel and riparian sediments - a transient storage pool for dissolved inorganic nitrogen. Biogeochemistry 26: 67-83.

Uehlinger, U., 2000. Resistance and resilience of ecosystem metabolism in a flood-prone river system. Freshwater Biology 45: 319-332.

Valett, H. M., J. A. Morice, C. N. Dahm \& M. E. Campana, 1996. Parent lithology, surfacegroundwater exchange, and nitrate retention in headwater streams. Limnology and Oceanography 41: 333-345.

von Schiller, D., E. Martí, J. L. Riera, M. Ribot, J. C. Marks \& F. Sabater. 2008. Influence of land use on stream ecosystem function in a Mediterranean catchment. Freshwater Biology 53: $2600-2612$.

Ward, J. V. \& J. A. Stanford (eds), 1979. The ecology of regulated streams. Plenum Press: New York, NY.

Webster, J. R. \& M. H. Valett, 2006. Solute dynamics. In Methods in stream ecology, F. R. Hauer and G. A. Lamberti (eds), Academic Press, San Diego, California.

Webster, J. R., P. J. Mulholland, J. L. Tank, H. M. Valett, W. K. Dodds, B. J. Peterson, W. B. Bowden, C. N. Dahm, S. Findlay, S. V. Gregory, N. B. Grimm, S. K. Hamilton, S. L. 

Wollheim, 2003. Factors affecting ammonium uptake in streams - an interbiome perspective. Freshwater Biology 48: 1329-1352. experiments to determine the effects of shade and plants on nutrient retention in a

527 lowland stream. Hydrobiologia 485: 153-169.

528 Wood, P. J. \& P. D. Armitage, 1997. Biological effects of fine sediment in the lotic environment. Environmental Management 21: 203-217.

530 Zarnetske, J. P., M. N. Gooseff, T. R. Brosten, J. H. Bradford, J. P. McNamara \& W. B. Bowden, 5312007 . Transient storage as a function of geomorphology, discharge, and permafrost 532 active layer conditions in Arctic tundra streams. Water Resources Research, 43. DOI:

$533 \quad 10.1029 / 2005$ WR004816. 
Table 1. Hydromorphological characteristics of the 5 hydropower plants where selected sites for this study were located (Franki, Plazaola, Mustar, Ameraun and Bertxin). Hydropower plants are arranged in the table following the downstream water flow. Dammed length corresponds to the length of the stream upstream from the dam subject to lentic conditions. $Q=$ discharge.

\begin{tabular}{cccccccc}
\hline $\begin{array}{c}\text { Hydropower } \\
\text { plant }\end{array}$ & $\begin{array}{c}\text { Dam } \\
\text { height } \\
(\mathrm{m})\end{array}$ & $\begin{array}{c}\text { Length of } \\
\text { diversion } \\
\text { canal } \\
(\mathrm{m})\end{array}$ & $\begin{array}{c}\text { Dammed } \\
\text { length } \\
(\mathrm{m})\end{array}$ & $\begin{array}{c}\text { Mean Q } \\
\text { in canals } \\
\left(\mathrm{L} \mathrm{s}^{-1}\right)\end{array}$ & $\begin{array}{c}\text { Concession } \\
\mathrm{Q} \\
\left(\mathrm{L} \mathrm{s}^{-1}\right)\end{array}$ & $\begin{array}{c}\text { Waterfall } \\
\text { height } \\
(\mathrm{m})\end{array}$ & $\begin{array}{c}\text { Annual energy } \\
\text { production } \\
(\mathrm{MWh})\end{array}$ \\
\hline Franki & 1.5 & 1100 & 50 & - & - & 30 & - \\
Plazaola & 5.5 & 1200 & 100 & 928 & 400 & 130.7 & 3.0 \\
Mustar & 3.1 & 3150 & 225 & 186 & 2000 & 52 & 1.1 \\
Ameraun & 4.1 & 4150 & 150 & 955 & 3000 & 54 & 4.3 \\
Bertxin & 5.8 & 3245 & 475 & 453 & 1000 & 103 & 3.2 \\
\hline
\end{tabular}


Table 2. Physical, chemical and biological characteristics measured in the canal and stream reaches of the 5 sites and in the reach upstream of the dam at Franki on the addition dates. Cond. = water conductivity. Chl $a$ and AFDM are chlorophyll $a$ and ash free dry mass, respectively, measured from stream cobbles or side-walls of the canals.

\begin{tabular}{|c|c|c|c|c|c|c|c|c|c|c|c|}
\hline & \multicolumn{3}{|c|}{ Franki } & \multicolumn{2}{|c|}{ Plazaola } & \multicolumn{2}{|c|}{ Mustar } & \multicolumn{2}{|c|}{ Ameraun } & \multicolumn{2}{|c|}{ Bertxin } \\
\hline & Upstream & Stream & Canal & Stream & Canal & Stream & Canal & Stream & Canal & Stream & Canal \\
\hline Reach length (m) & 65 & 8 & 95 & 83 & 180 & 95 & 130 & 99 & 108 & 89 & 59 \\
\hline Canopy cover (\%) & 82.00 & 82.00 & 77.27 & 82.00 & 48.45 & 74.32 & 82.00 & 51.07 & 71.60 & 55.08 & 22.24 \\
\hline Radiation $\left(\mathrm{w} \mathrm{m}^{-2}\right.$ ) & 99.0 & 126.2 & 24.7 & 26.0 & 33.7 & 211.9 & 89.1 & 204.7 & 102.4 & 296.3 & 134.9 \\
\hline Water temp. $\left({ }^{\circ} \mathrm{C}\right)$ & 12.2 & 12.0 & 11.1 & 14.2 & 14.2 & 16.0 & 15.1 & 18.2 & 15.8 & 16.8 & 16.5 \\
\hline Cond. $\left(\mu \mathrm{S} \mathrm{cm}^{-1}\right)$ & 65.7 & 79.0 & 67.2 & 259.1 & 250.8 & 215.1 & 217.6 & 203.9 & 205.6 & 122.0 & 121.7 \\
\hline $\mathrm{pH}$ & 7.07 & - & - & 7.80 & - & 7.83 & - & 8.10 & - & 7.48 & - \\
\hline Dissolved $\mathrm{O}_{2}\left(\mathrm{mg} \mathrm{L}^{-1}\right)$ & 104 & - & - & 100.5 & - & 104.5 & - & 106 & - & 102.9 & - \\
\hline $\mathrm{PO}_{4}^{3-}-\mathrm{P}\left(\mathrm{mg} \mathrm{L}^{-1}\right)$ & 0.010 & 0.029 & 0.011 & 0.050 & 0.060 & 0.011 & 0.016 & 0.034 & 0.034 & 0.007 & 0.004 \\
\hline $\mathrm{NH}_{4}^{+}-\mathrm{N}\left(\mathrm{mg} \mathrm{L}^{-1}\right)$ & - & 0.020 & 0.044 & 0.039 & 0.036 & 0.009 & 0.008 & 0.039 & 0.036 & - & 0.028 \\
\hline $\mathrm{Chl} a\left(\mathrm{mg} \mathrm{m}^{-2}\right)$ & 26.9 & 2.4 & 120.5 & 85.8 & 20.4 & 22.6 & - & 88.7 & 16.1 & 29.7 & 30.4 \\
\hline $\operatorname{AFDM}\left(\mathrm{g} \mathrm{m}^{-2}\right)$ & 10.6 & 3.9 & 13.4 & 18.1 & 4.3 & 5.8 & - & 21.8 & 8.6 & 16.8 & 20.1 \\
\hline
\end{tabular}


Table 3. Morphological and hydraulic parameters. Water transient storage zone parameters estimated using OTIS model in the canal and stream reaches of the five sites and upstream the dam at Franki at the addition dates.

\begin{tabular}{|c|c|c|c|c|c|c|c|c|c|c|c|}
\hline & \multicolumn{3}{|c|}{ Franki } & \multicolumn{2}{|c|}{ Plazaola } & \multicolumn{2}{|c|}{ Mustar } & \multicolumn{2}{|c|}{ Ameraun } & \multicolumn{2}{|c|}{ Bertxin } \\
\hline & Upstream & Stream & Canal & Stream & Canal & Stream & Canal & Stream & Canal & Stream & Canal \\
\hline Clay (\%) & 0 & 0 & 0 & 0 & 0 & 0 & 0 & 0.9 & 0 & 0 & 0 \\
\hline Silt (\%) & 0 & 0 & 0 & 0.7 & 0 & 4.1 & 0 & 0 & 0 & 2.6 & 0 \\
\hline Sand (\%) & 16.0 & 0 & 9.3 & 3.4 & 0 & 0 & 0 & 2.8 & 0 & 0 & 0 \\
\hline Gravel (\%) & 8.0 & 14.3 & 0 & 10.2 & 0 & 15.5 & 0 & 10.4 & 0 & 8.8 & 0 \\
\hline Pebble (\%) & 8.0 & 0 & 2.3 & 10.2 & 0 & 0 & 0 & 16.9 & 0 & 0 & 0 \\
\hline Cobble (\%) & 22.0 & 28.6 & 0 & 23.8 & 0 & 34.5 & 0 & 42.5 & 0 & 28.1 & 0 \\
\hline Boulder (\%) & 12.0 & 22.7 & 0 & 29.9 & 0 & 30.4 & 0 & 16.0 & 0 & 33.8 & 0 \\
\hline Rock (\%) & 34.0 & 31.4 & 0 & 21.8 & 0 & 15.5 & 0 & 10.4 & 0 & 26.3 & 0 \\
\hline Concrete (\%) & 0 & 0 & 86.0 & 0 & 59.1 & 0 & 100 & 0 & 100 & 0 & 100 \\
\hline Wood (\%) & 0 & 0 & 0 & 0 & 0 & 0 & 0 & 0 & 0 & 0.4 & 0 \\
\hline Litter (\%) & 0 & 2.9 & 2.3 & 0 & 40.9 & 0 & 0 & 0 & 0 & 0 & 0 \\
\hline$Q\left(L s^{-1}\right)$ & 77.5 & 0.8 & 76.2 & 139.1 & 496.4 & 201.1 & 645.5 & 79.7 & 789.9 & 381.5 & 61.6 \\
\hline$\%$ of total Q & 100 & 1.0 & 99.0 & 21.9 & 78.11 & 23.8 & 76.3 & 9.2 & 90.8 & 86.1 & 13.9 \\
\hline Wetted width $(\mathrm{m})$ & 4.00 & 0.40 & 1.41 & 9.00 & 2.67 & 8.00 & 2.00 & 6.50 & 2.30 & 10.72 & 0.87 \\
\hline Depth (m) & 0.16 & 0.04 & 0.26 & 0.17 & 0.96 & 0.20 & 0.80 & 0.09 & 0.90 & 0.21 & 0.19 \\
\hline Avg. velocity $\left(\mathrm{m} \mathrm{s}^{-1}\right)$ & 0.17 & 0.02 & 0.33 & 0.14 & 0.29 & 0.31 & 0.52 & 0.15 & 0.51 & 0.22 & 0.37 \\
\hline$A\left(m^{2}\right)$ & 0.47 & 0.04 & 0.23 & 0.93 & 1.61 & 0.66 & 1.22 & 0.52 & 1.54 & 1.76 & 0.15 \\
\hline As $\left(m^{2}\right)$ & 0.12 & 0.03 & 0.03 & 0.18 & 0.22 & 0.23 & 0.07 & 0.10 & 0.02 & 0.27 & 0.03 \\
\hline
\end{tabular}




\begin{tabular}{rlllllllllll} 
As/A & 0.25 & 0.77 & 0.13 & 0.19 & 0.14 & 0.35 & 0.05 & 0.18 & 0.01 & 0.15 & 0.19 \\
$\mathrm{k}_{1}\left(\mathrm{~min}^{-1}\right)$ & 0.18 & 0.20 & 0.20 & 0.12 & 0.36 & 0.33 & 0.24 & 0.09 & 0.09 & 0.12 & 1.71 \\
$\mathrm{k}_{2}\left(\mathrm{~min}^{-1}\right)$ & 0.71 & 0.26 & 1.53 & 0.62 & 2.63 & 0.94 & 4.50 & 0.49 & 9.22 & 0.80 & 9.20 \\
\hline
\end{tabular}


Table 4. Mean values and standard deviation of uptake length (Sw), mass transfer coefficient (Vf) and ambient uptake rate (U) of $\mathrm{PO}_{4}{ }^{3-}-\mathrm{P}$ and $\mathrm{NH}^{4+}-\mathrm{N}^{2}$ at the canal and stream reaches. Lowest row shows result of paired Student's t-test.

\begin{tabular}{|c|c|c|c|c|c|c|}
\hline & \multicolumn{3}{|c|}{$\mathrm{PO}_{4}^{3-}-\mathrm{P}$} & \multicolumn{3}{|c|}{$\mathrm{NH}_{4}^{+}-\mathrm{N}$} \\
\hline & $\mathrm{S}_{\mathrm{w}}(\mathrm{m})$ & $V_{f}\left(m m m^{-1}\right)$ & $\mathrm{U}\left(\mu \mathrm{g} \mathrm{m}^{-2} \mathrm{~s}^{-1}\right)$ & $\mathrm{S}_{\mathrm{w}}(\mathrm{m})$ & $V_{f}\left(m m m^{-1}\right)$ & $U\left(\mu \mathrm{g} \mathrm{m}^{-2} \mathrm{~s}^{-1}\right)$ \\
\hline Stream & $93.8 \pm 68.6$ & $12.12 \pm 5.43$ & $5.02 \pm 4.33$ & $146.5 \pm 56.6$ & $5.05 \pm 2.89$ & $2.02 \pm 1.28$ \\
\hline Canal & $354.0 \pm 235.5$ & $32.98 \pm 37.05$ & $10.57 \pm 10.31$ & $284.1 \pm 200.7$ & $32.48 \pm 22.82$ & $12.82 \pm 7.67$ \\
\hline \multirow[t]{2}{*}{ Paired Student t-test } & $\mathrm{t}=-1.914$ & $t=-1.514$ & $t=-0.741$ & $t=-2.591$ & $t=-7.920$ & $t=-6.956$ \\
\hline & n.s. & n.s. & n.s. & n.s. & $p=0.004$ & $p=0.006$ \\
\hline
\end{tabular}




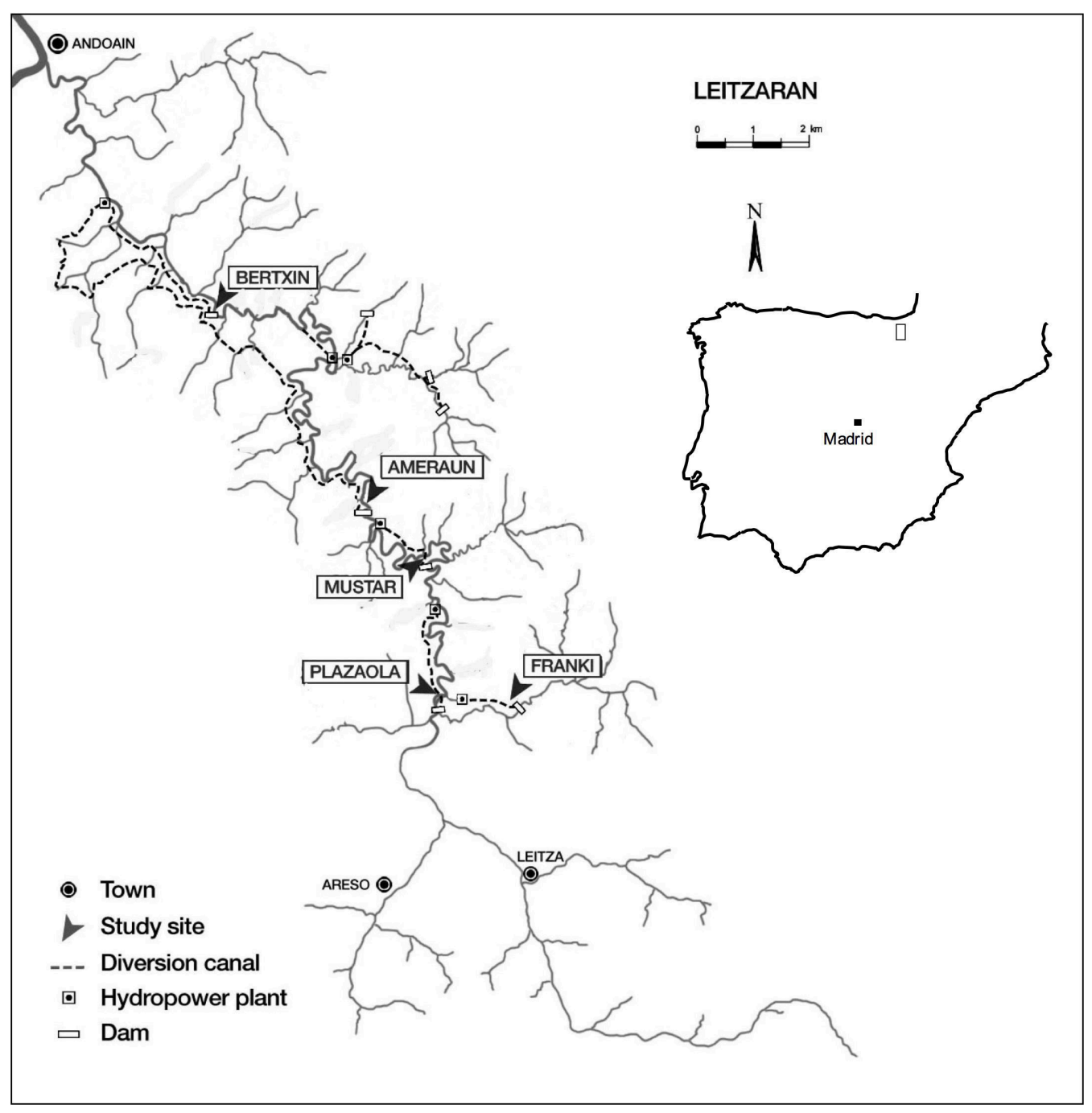

Figure 1. Leitzaran catchment, with the hydropower plants still operating and respective dam and diversion canals. 


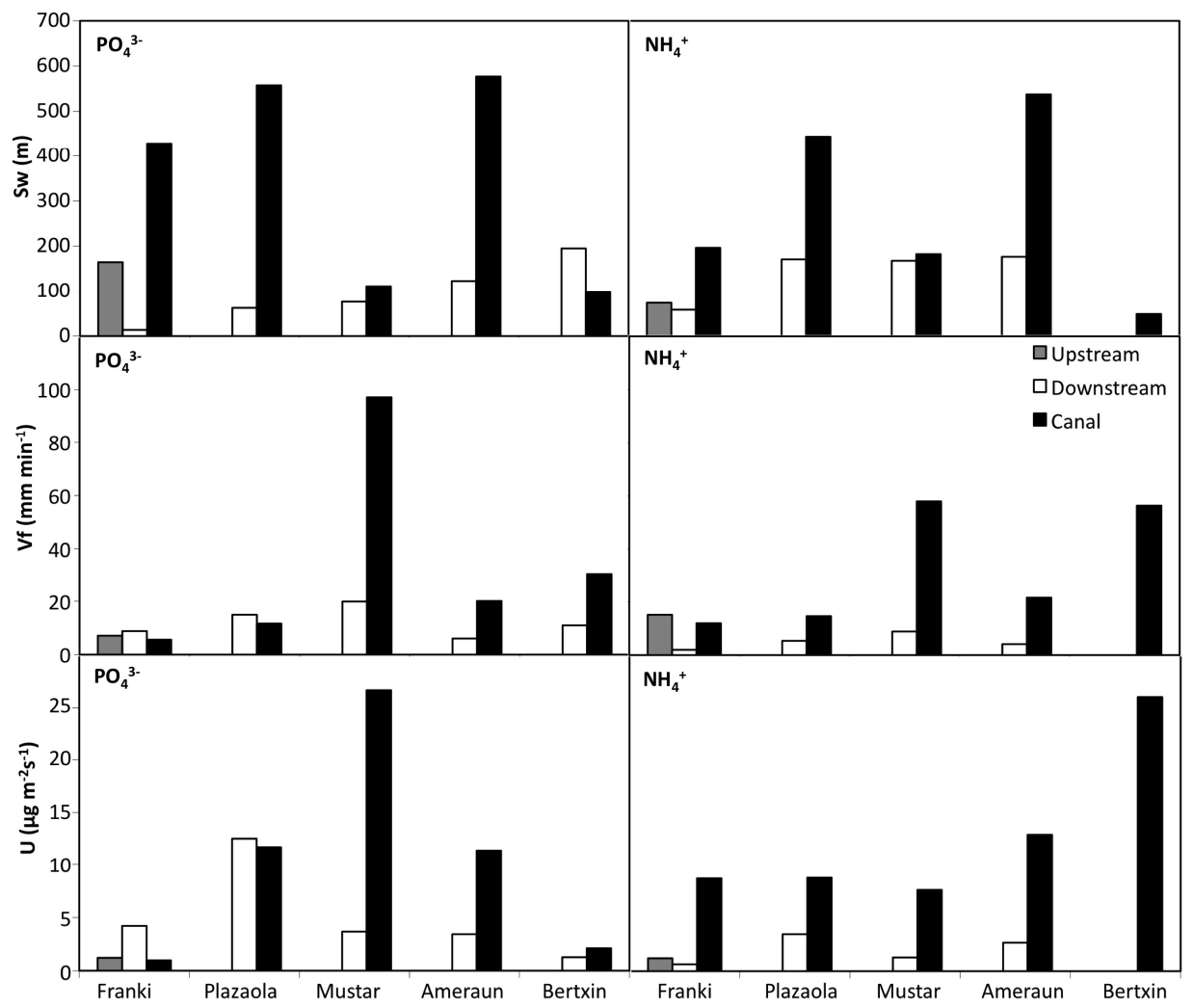

Figure 2. Parameters of nutrient retention, uptake length $\left(S_{w}\right)$, mass transfer coefficient $\left(V_{f}\right)$ and ambient uptake rate $(\mathrm{U})$ of $\mathrm{PO}_{4}{ }^{3-}-\mathrm{P}$ and $\mathrm{NH}_{4}{ }^{+}-\mathrm{N}$ upstream from the dam (Franki), at stream channels below the dam and at diversion canals. Study sites are arranged in the $\mathrm{x}$ axis following the downstream flow. Ammonium data for Franki upstream and Bertxin stream not available. 


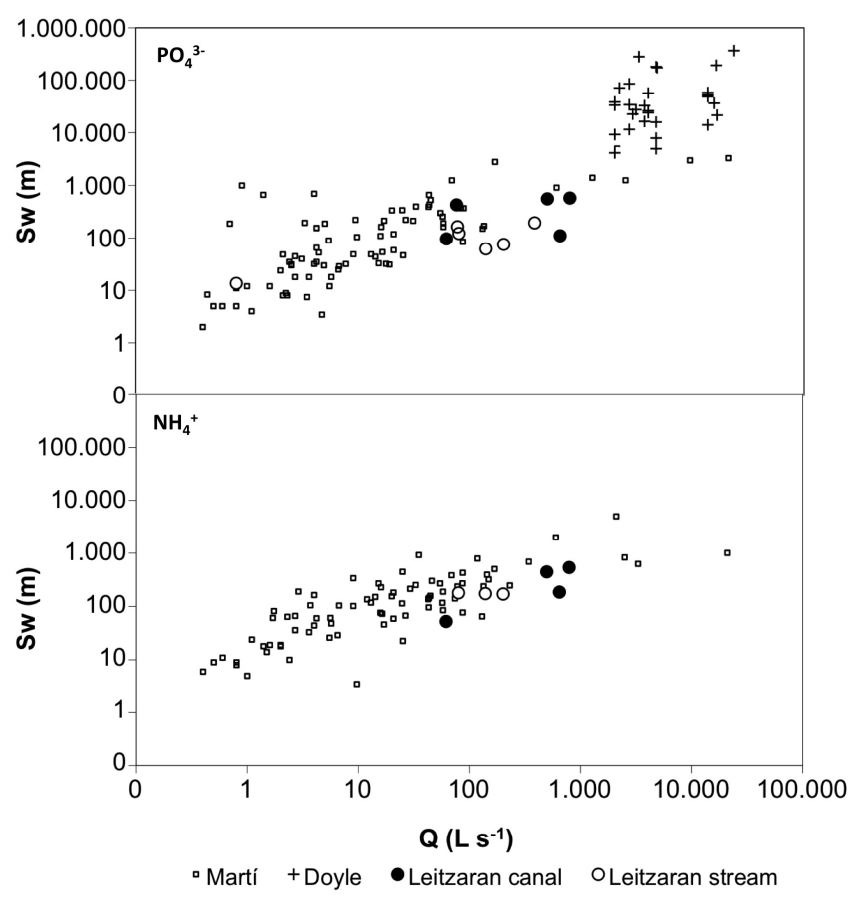

Figure 3. Comparison of uptake length for phosphate and ammonium in the present study with data from the literature, expanded from Martí et al. (2004) and values reported by Doyle et al. (2003) from the Koshkonong River. 